\section{In-row Diploid Watermelon Pollenizer Competition with Triploid Watermelon Based on Four Planting Ratios}

\author{
Joshua I. Adkins ${ }^{1,3}$, Joshua H. Freeman ${ }^{1,2}$, and Stephen M. Olson ${ }^{1}$
}

AdDitional INDEX wORDs. Citrullus lanatus, seedless, seeded

Summary. Diploid watermelon (Citrullus lanatus) pollenizers are planted within triploid watermelon fields to provide viable pollen for triploid fruit set. In recent years, pollenizer cultivars with desirable characteristics for planting in-row with triploid watermelons have been commercially available. The degree of plant competition from in-row pollenizers grown in the commercially common arrangement where pollenizers are placed equidistant from neighboring triploid plants has not been reported. Field experiments were conducted in 2005, 2006, and 2007 in Quincy, FL, to examine the competitive impact of in-row pollenizers grown equidistant from neighboring triploid plants. Four ratios of pollenizers-to-triploids: $1: 1,1: 2,1: 3$, and $1: 4$ were used to provide various levels of pollenizer competition. No significant difference in yield based on the weight or number of fruit per triploid plant resulted from the varied pollenizer ratios. Therefore, pollenizers grown in-row at an equidistant spacing from the neighboring triploid plants had no competitive impact on the yield of the triploid watermelon crop.

$\mathrm{T}$ riploid (seedless) watermelons accounted for $\approx 89 \%$ of the watermelons grown in the United States in 2010 (U.S. Department of Agriculture, 2011). Special production considerations must be taken into account when growing triploid watermelons. Staminate triploid watermelon flowers do not produce enough viable pollen for fruit set (Maynard, 2003; Maynard and Elmstrom, 1992). Therefore, diploid (seeded) watermelon pollenizers are planted within the field to provide pollen for the pistillate triploid flowers. Incorporating the pollenizers into the field arrangement may be accomplished by dedicating certain rows to pollenizers or by interplanting the pollenizers within the rows of triploids (Freeman et al., 2007b; Maynard, 2003). In recent years, pollenizer cultivars with desirable characteristics for planting in-row with triploid watermelons have been commercially available (Freeman et al., 2007a). These characteristics include: abundant staminate flowers and pollen, noncompetitive growth habit (e.g., reduced

${ }^{1}$ Horticultural Sciences Department, North Florida Research and Education Center, University of Florida, 155 Research Road, Quincy, FL 32351

${ }^{2}$ Current address: Department of Horticulture, Eastern Shore Agricultural Research and Extension Center, Virginia Polytechnic Institute and State University, 33446 Research Drive, Painter, VA 23420.

${ }^{3}$ Corresponding author. E-mail: jia84@ufl.edu. foliage), and a rind pattern or fruit size that is distinct (for identification during triploid harvest). When pollenizers are planted in-row with the triploids, the dedicated rows for pollenizers are eliminated (Freeman and Olson, 2007). Therefore, the number of triploid watermelon plants per area is increased.

Pollenizer frequencies ranging from $20 \%$ to $33 \%$ of the total plants in the field have been recommended (Fiacchino and Walters, 2003; Maynard, 2003; NeSmith and Duval, 2001). These findings are based on various field arrangements. Freeman et al. (2007b) stated that a $1: 3$ pollenizer-totriploid ratio is recommended for most in-row pollenizers.

Only a limited amount of research has been published regarding the competitiveness of in-row pollenizers with neighboring triploid plants. Freeman et al. (2007b) conducted a study to examine five in-row spacings between pollenizer and triploid plants. As spacing between the pollenizer and triploid plants increased, there was a linear increase in triploid yield in response to the lower competition. The degree of competition from in-row pollenizers grown in the commercially common arrangement where pollenizers are placed equidistant from neighboring triploids has not been reported. The objective of this research was to examine the competitive impact of in-row pollenizers grown equidistant from neighboring triploid plants by using four ratios of pollenizers-to-triploids.

\section{Materials and methods}

Field studies were conducted in 2005, 2006, and 2007 at the North Florida Research and Education Center (NFREC) in Quincy, FL. Soil type at the NFREC is a Norfolk loamy sand (fine-loamy, kaolinitic, thermic Typic Kandiudults). Before planting, raised beds were fumigated with methyl bromide and chloropicrin (67:33) at 350 $\mathrm{lb} / \mathrm{acre}$ and covered with black polyethylene mulch. Beds were established on 8 -ft centers. Experimental design was a randomized complete block.

'Super Crisp' (Zeraim Gedera, Gedera, Israel) triploid watermelon seedlings and 'SP-4' (Syngenta Seeds, Boise, ID) diploid watermelon pollenizer seedlings grown at NFREC were transplanted on 31 Mar. 2005, 27 Mar. 2006, and 20 Mar. 2007. Triploid watermelons were grown at an in-row spacing of 40 inches. Pollenizers were established at four ratios of pollenizers-to-triploids: $1: 1,1: 2$, $1: 3$, and $1: 4$ (Fig. 1 ) to provide various levels of pollenizer competition with the triploids. Each pollenizer was transplanted immediately between triploid plants (20 inches from either triploid). Eight triploid plants were included in each plot with the exception of the $1: 3$ ratio where it was more appropriate to use nine plants per plot.

Plots were irrigated daily via drip tape that was placed under the mulch. Irrigation rate varied based on season and plant size. All fertilizer was applied preplant at $146 \mathrm{lb} /$ acre nitrogen, $20 \mathrm{lb} /$ acre phosphorus, and $121 \mathrm{lb} /$ acre potassium. University of Florida

\begin{tabular}{llll}
\hline $\begin{array}{l}\text { Units } \\
\begin{array}{l}\text { To convert U.S. to SI, } \\
\text { multiply by }\end{array}\end{array}$ & U.S. unit & SI unit & $\begin{array}{l}\text { To convert SI to U.S., } \\
\text { multiply by }\end{array}$ \\
\hline 0.3048 & $\mathrm{ft}$ & $\mathrm{m}$ & 3.2808 \\
2.54 & inch $(\mathrm{es})$ & $\mathrm{cm}$ & 0.3937 \\
0.4536 & $\mathrm{lb}$ & $\mathrm{kg}$ & 2.2046 \\
1.1209 & $\mathrm{lb} / \mathrm{acre}$ & $\mathrm{kg} \cdot \mathrm{ha}^{-1}$ & 0.8922
\end{tabular}




\begin{tabular}{|c|c|c|c|}
\hline & & $\mathrm{T}$ & \\
$\mathrm{T}$ & $\mathrm{T}$ & $\mathrm{T}$ & $\mathrm{T}$ \\
$\mathbf{P}$ & & & \\
$\mathrm{T}$ & $\mathrm{T}$ & $\mathrm{T}$ & $\mathrm{T}$ \\
$\mathbf{P}$ & $\mathbf{P}$ & $\mathbf{P}$ & \\
$\mathrm{T}$ & $\mathrm{T}$ & $\mathrm{T}$ & $\mathrm{T}$ \\
$\mathbf{P}$ & & & \\
$\mathrm{T}$ & $\mathrm{T}$ & $\mathrm{T}$ & $\mathrm{T}$ \\
$\mathbf{P}$ & $\mathbf{P}$ & & $\mathbf{P}$ \\
$\mathrm{T}$ & $\mathrm{T}$ & $\mathrm{T}$ & $\mathrm{T}$ \\
$\mathbf{P}$ & & $\mathbf{P}$ & \\
$\mathrm{T}$ & $\mathrm{T}$ & $\mathrm{T}$ & $\mathrm{T}$ \\
$\mathbf{P}$ & $\mathbf{P}$ & & \\
$\mathrm{T}$ & $\mathrm{T}$ & $\mathrm{T}$ & $\mathrm{T}$ \\
$\mathbf{P}$ & & & \\
$\mathrm{T}$ & $\mathrm{T}$ & $\mathrm{T}$ & $\mathrm{T}$ \\
$\mathbf{P}$ & $\mathbf{P}$ & $\mathbf{P}$ & $\mathbf{P}$ \\
$1: 1$ & $1: 2$ & $1: 3$ & $1: 4$ \\
\hline
\end{tabular}

Fig. 1. Diagram representing the plot arrangement of each 'SP-4' pollenizer watermelon (P) and 'Super Crisp' triploid watermelon $(\mathrm{T})$ at four $\mathrm{P}: \mathrm{T}$ ratios.

Institute of Food and Agricultural Sciences recommendations were followed for pesticide applications (Olson et al., 2004).

Triploid watermelons were harvested in 2005 on 22 June [ $83 \mathrm{~d}$ after transplanting (DAT)], 29 June (90 DAT), and 8 July (99 DAT); in 2006 on 12 June (77 DAT), 20 June (85 DAT), 28 June (93 DAT), and 10 July (105 DAT); and in 2007 on 13 June (85 DAT), 26 June (98 DAT), and 6 July (108 DAT). Individual weights were recorded for each fruit. Analysis of variance was conducted to test for significant treatment effects and interactions (SAS version 9.1; SAS Institute, Cary, NC). Mean separations were performed using Duncan's multiple range test $(\alpha=0.05)$.

\section{Results and discussion}

Yield based on the weight and number of fruit per triploid plant was significantly lower in 2005 compared with that of the other 2 years of the study, when averaged across planting ratios (Table 1). Each year, fruit size varied significantly. There was no interaction between planting ratio and year. Therefore, all data from the 3year study were combined (Table 1).

No significant difference in yield based on the weight or number of fruit

Table 1. Effect of 'SP-1' pollenizer watermelon to 'Super Crisp' triploid watermelon ratio on yield (weight and number of fruit) per triploid plant and fruit size.

\begin{tabular}{cccc}
\hline & ${\text { Yield }\left(\mathbf{l b} / \text { plant }^{\mathrm{z}}\right.}$ & Fruit $($ no./plant $)$ & Fruit size $(\mathbf{l b})$ \\
\hline Ratio & & & \\
$1: 1$ & 48.50 & 3.24 & $14.95 \mathrm{~b}^{\mathrm{y}}$ \\
$1: 2$ & 48.63 & 2.99 & $16.16 \mathrm{a}$ \\
$1: 3$ & 50.61 & 3.07 & $16.51 \mathrm{a}$ \\
$1: 4$ & 49.38 & 3.12 & $16.02 \mathrm{a}$ \\
Year & & & \\
2005 & $43.55 \mathrm{~b}$ & $2.75 \mathrm{~b}$ & $15.86 \mathrm{~b}$ \\
2006 & $54.50 \mathrm{a}$ & $3.19 \mathrm{a}$ & $16.99 \mathrm{a}$ \\
2007 & $49.79 \mathrm{a}$ & $3.37 \mathrm{a}$ & $14.89 \mathrm{c}$ \\
Probability & & & $*$ \\
Ratio & $\mathrm{NS}$ & $\mathrm{NS}$ & $* * *$ \\
Year & $* *$ & $* * *$ & $\mathrm{NS}$ \\
Ratio $\times$ year & $\mathrm{NS}$ & $\mathrm{NS}$ & \\
\hline
\end{tabular}

${ }^{\mathrm{z}} 1 \mathrm{lb}=0.4536 \mathrm{~kg}$.

'When significant effects were found, means were separated with Duncan's multiple range test $(\alpha=0.05)$. When comparing by ratio or year, means within columns followed by the same letter are not significantly different.

${ }^{\mathrm{x}_{\mathrm{NS}},{ }^{*}, * *},{ }^{* *}$ Nonsignificant or significant at $P \leq 0.05,0.01$, or 0.001 , respectively.

per triploid plant resulted from the varied planting ratios. At the $1: 2,1: 3$, and $1: 4$ planting ratios, average fruit size was consistent at $16.16,16.52$, and $16.02 \mathrm{lb}$, respectively. Fruit size was significantly smaller $(14.95 \mathrm{lb})$ at the $1: 1$ planting ratio compared with all other planting ratios.

Smaller fruit size at the 1:1 planting ratio is likely the result of slightly higher (although not statistically significant) fruit number per plant. The similar yields across planting ratios would imply that neither the greater competition expected at higher pollenizer rates nor the lower availability of pollen expected at the lower pollenizer rates resulted in a yield decrease. However, it would be difficult to attribute any yield variation between ratios to competition or pollen availability specifically. The results of this experiment indicate that when pollenizers are grown in-row at an equidistant spacing from the neighboring triploid plants, there is no competitive impact on the yield of the triploid watermelon crop.

\section{Literature cited}

Fiacchino, D.C. and S.A. Walters. 2003. Influence of diploid pollenizer frequencies on triploid watermelon quality and yields. HortTechnology 13:58-61.

Freeman, J.H., G.A. Miller, S.M. Olson, and W.M. Stall. 2007a. Diploid water- melon pollenizer cultivars differ with respect to triploid watermelon yield. HortTechnology 17:518-522.

Freeman, J.H. and S.M. Olson. 2007. Using In-Row Pollenizers for Seedless Watermelon Production. Univ. Florida, Inst. Food Agr. Sci. Ext. HS1079. 1 June 2011. <http://edis.ifas.ufl.edu/hs333>.

Freeman, J.H., S.M. Olson, and W.M. Stall. 2007b. Competitive effect of in-row diploid watermelon pollenizers on triploid watermelon yield. HortScience 42: 1575-1577.

Maynard, D.N. 2003. Growing Seedless Watermelon. Univ. Florida, Inst. Food Agr. Sci. Ext. HS687. I June 2011. $<$ http://edis.ifas.ufl.edu/cv006>.

Maynard, D.N. and G.W. Elmstrom. 1992. Triploid watermelon production practices and varieties. Acta Hort. 318:169-173.

NeSmith, D.S. and J.R. Duval. 2001. Fruit set of triploid watermelons as a function of distance from a diploid pollinizer. HortScience 36:60-61.

Olson, S.M., E.H. Simonne, D.N. Maynard, G.J. Hochmuth, C.S. Vavrina, W.M. Stall, T.A. Kucharek, S.E. Webb, T.G. Taylor, and S.A. Smith. 2004. Cucurbit production in Florida, p. 169-197. In: S.M. Olson and E. Simonne (eds.). Vegetable production handbook for Florida. Univ. Florida, Inst. Food Agr. Sci. Ext. and Vance Publishing, Lincolnshire, IL.

U.S. Department of Agriculture. 2011. Agricultural Marketing Service Custom Report. 1 June 2011. <http://marketnews. usda.gov/portal/fv>. 